УДК 347.43

\author{
I.I. Яворський \\ аспірант кафедри фінансового права \\ Національного університету державної фіскальної служби України
}

\title{
АКТУАЛЬНІ ПРОБЛЕМИ ВИЗНАЧЕННЯ ПРОЦЕСУАЛЬНИХ НОРМ БЮДЖЕТНОГО ПРАВА
}

Необхідність комплексного вивчення основних проблем, пов'язаних із бюджетною діяльністю, особливо гостро відчувається в Україні останніми роками. Економічні та соціальні перетворення в Україні протягом 2014-2019 рр. потребують негайного вирішення та зумовлюють необхідність побудови адекватного фінансово-бюджетного механізму, який би став ефективним інструментом реалізації бюджетної політики держави. Як слушно зазначається в юридичній літературі, українське фінансове законодавство інтенсивно почало формуватися на початку $90-\mathrm{x}$ р. XX ст. й упродовж усього часу існування піддається змінам і доповненням. Натомість слід зазначити, що фінансове законодавство в Україні не є достатньо систематизованим і кодифікованим. Водночас досягнення стійкого та стабільного соціально-економічного зростання в Україні неможливе без створення оптимальної системи бюджетних відносин. Не останнє місце в цьому процесі має відводитися вивченню особливостей застосування та реалізації бюджетно-процесуальних норм.

Для досягнення поставленої мети перед автором сформульовані наступні завдання: по-перше, надати правову характеристику процесуальних норм бюджетного права, визначити їх поняття, сутність i місце в системі бюджетного права; по-друге, розглянути джерела, що містять процесуальні норми бюджетного права; nо-третє, схарактеризувати систему процесуальних норм бюджетного права та визначити правовий механізм їхньої реалізації; по-четверте, проаналізувати актуальні проблеми щодо реалізації процесуальних норм бюджетного права в Україні та сформулювати пропозиції до бюджетного законодавства в частині вдосконалення процесуальних норм бюджетного права.

Теоретичну основу дослідження склали наукові роботи вітчизняних і зарубіжних учених-юристів, зокрема С.С. Алексєєва, Г.В. Атаманчука, I.Т. Балабанова, О.Д. Василика, Л.К. Воронової, I.П. Голосніченка, О.М. Горбунової, В.М. Горшенєва, О.Ю. Грачової, Л. Дюгі, П.Ф. Єлісейкіна, Т.С. Єрмакова, І.Б. Заверухи, Л.А. Зубченко, Н.К. Ісаєвої, С.Т. Кадькаленка, М.В. Карасьової, К. Кіллєна, Д.А. Ковачева, А.М. Козиріна, В.О. Котюка, М.П. Кучерявенка, В.О. Лебедєва, B.О. Лучина, Л.П. Маслій, Н.I. Матузова, А.А. Нечай, І.Х. Озерова, Л.А. Савченко, М.Ф. Селивона, О.Ф. Скакун, В.Д. Сорокіна, Н.В. Теремцової, Г.П. Толстопятенко, Н.М. Травкіної,
Ю.О. Тихомірова, Н.І. Хімічевої, О.І. Худякова, В.Д. Чернадчука, Р.В. Шагієвої, О.Б. Шемякіної, М.К. Якимчука, Х.П. Ярмакі та ін.

Водночас варто відзначити, що спеціального комплексного дослідження бюджетно-процесуальних норм у вітчизняній фінансово-правовій науці ще не проводилося.

Постановка завдання. Метою статті є дослідження нормативно-правового забезпечення та закріплення процесуальних норм бюджетного права з виявленням проблемних аспектів і колізій вітчизняного законодавства у ці сфері.

Виклад основного матеріалу. Критерієм, що слугує з'ясуванню сутності бюджетного процесу, є нормативна його основа, а саме таких її складників, як матеріальні та процесуальні норми. Таке твердження базується на тому, що юридичний процес регулюється процесуальними нормами, а його реалізація пов' язана з матеріальними нормами [1]. Слід зазначити, що проблема розмежування матеріальних і процесуальних норм зумовлена існуванням двох протилежних позицій: запереченням необхідності поділу всіх норм на процесуальні і матеріальні (П.М. Рабинович, О.В. Фатхутдінова та ін.) або визнанням. Одні автори, розмежовуючи, не вказують на відповідний критерій поділу, інші називають доволі різноманітні підстави [2].

Для фінансового права характерним є визнання поділу фінансово-правових норм на матеріальні та процесуальні. Це підтверджується в академічних [3; 4] і наукових [5] працях. Водночас існують і певні застереження такого поділу. Зокрема, С.В. Янкевич вказує на існування процесуальних норм лише в бюджетній підгалузі фінансово-правової науки, що видається, на нашу думку, не обгрунтованим, адже ціла низка вчених, зокрема в галузі податкового права, наголошують на існуванні в рамках фінансово-правових норм такого їх різновиду, як податкові процесуальні норми (О.С. Башняк, Д.О. Білінський, 3.М. Будько, Л.В. Жук, І.Є. Криницький, М.П. Кучерявенко, В.П. Печуляк, С.В. Сарана та ін.) [6; 7].

Особливо проявляється диференціація матеріальних і процесуальних норм у стрижневій підгалузі фінансового права - бюджетному праві. На цьому, зокрема, наголошують Н.I. Хімічева, M.I. Піскотін та інші провідні вчені.

Традиційно бюджетний процес у фінансово-правовій науці розглядається як процесуальний інститут бюджетного права, норми якого визначають: 
склад суб'єктів (учасників) конкретного виду діяльності, зокрема бюджетної; перелік видів необхідних дій і їх чітку послідовність (наприклад, ст. 19 Бюджетного кодексу (далі - БКУ) прямо визначає стадії бюджетного процесу); організаційне та інституційне забезпечення кожної дії, стадії (йдеться про те, які органи влади мають вчиняти ті чи інші дії, а також коли і як саме). У більшості підручників із фінансового права та монографій iз бюджетного права вчені наголошують на тому, що норми бюджетного права поділяються на матеріальні та процесуальні. Зовсім не йдеться про поділ бюджетного права як підгалузі (інститути) фінансового права на якість відокремлені частини. Поділ норм бюджетного права на матеріальні та процесуальні є настільки реальним і чітким, що випливає із характеру та ролі бюджетного права, і його дотримуються (цілком або частково) всі, хто намагається класифікувати ці норми [8].

Натомість вченими, які позиціюють бюджетний процес через призму юридичного процесу, зміст бюджетно-процесуальних норм розглядається дещо з інших позицій: 1) переважно розкривається в межах відносин, що пов'язані лише з проходженням самого бюджету, ігноруючи інші види бюджетних правовідносин [9]; 2) розширення кола бюджетно-процесуальних відносин: а) що відбувається в межах бюджетного процесу (додаються лише окремі види відносин). Наприклад, такий вид відносин, як застосування заходів примусу за порушення бюджетного законодавства [10]; б) рідше -передбачає охоплення бюджетних правовідносин, що виходять за межі бюджетного процесу.

Зокрема, М.Б. Разгільдієва, досліджуючи бюджетний процес, визначає його поняття у вузькому та широкому розумінні. Слід відзначити, що дефініція широкого трактування формально відповідає поняттю бюджетно-правового процесу, оскільки зміст визначення охоплює діяльність учасників бюджетного процесу, спрямовану на забезпечення у формі бюджету виконання функцій держави (муніципальних утворень) шляхом ефективного здійснення покладених на них видаткових зобов'язань [7], тобто діяльність, що не обмежується лише проходженням бюджету.

На противагу цьому В.Є. Мартиненко робить висновок про те, що бюджетне право складається 3 двох інститутів: 1. матеріального бюджетного права, яке є сукупністю матеріальних норм бюджетного права; 2. процесуального бюджетного права, що є сукупністю процесуальних норм бюджетного права, які поділяються на: компетенційні (визначають комтепенцію (повноваження) учасників бюджетного процесу та процедурні (регуллють різноманітні процедури, котрі виникають у ході бюджетного процесу [11].

У цьому звязку можна погодитися з С.С. Теленик, що такий поділ повторює традиційний поділ бюджетного права на бюджетний устрій і бюджетний процес. Проте, на його думку, наведений висновок В.С. Мартиненка є не просто авторським баченням, а є таким, що ускладнює розуміння самого бюджетного права та його норм. Вказані вище компетенційні норми є, на думку C.C. Теленика, не процесуальними, а матеріальними, до того ж, різногалузевими [12].

Крім того, вважаємо, що, якщо говорити про існування матеріального бюджетного права як частини бюджетного права, то проблематично окреслити матеріальні бюджетні правовідносини. Ще більш ускладнює проблему наступна теза В.Є. Мартиненка про те, що «правові норми, які регулюють бюджетний процес, формуюють інститут загальної частини бюджетного права, котрий доцільно йменувати «процесуально-бюджетне право», предметом якого $€$ бюджетно-процесуальні відносини» [11]. Виходить, що, окрім поділу бюджетного права на норми та інститути, виділяються ще й окремі частини. Теоретично можна розділити багато що, проте практичного значення воно не матиме, внесе лише доктринальний спір і з часом взагалі забудеться, якщо не знайдуться прихильники.

Як вже вище зазначалося, однією 3 вітчизняних Ірунтовних праць, що розкриває сутність і зміст бюджетно-процесуальних норм, є дисертація Н.В. Теремцової. Вчена всебічно дослідила особливості означеного виду норм та окреслила відмінності їх від процесуальних норм інших галузей права, а також від матеріальних бюджетноправових правил [13].

Так, зокрема, під бюджетно-процесуальною нормою вищеназвана авторка пропонує розуміти загальнообов'язкове, формально визначене правило, що встановлюється від державою й органами місцевого самоврядування, це приписи, які охороняються примусовою силою держави, направлені на забезпечення реалізації матеріальних бюджетно-правових норм за допомогою регулювання процесуальних відносин щодо складання, розгляду, затвердження і виконання бюджетів, підготовки, розгляду і затвердження звітів про виконання бюджетів, а також контролю за їх виконанням і внесенню змін в окремі бюджетні показники через закріплення різних початкових положень (дефініцій, принципів і т.п.) і визначення процесуальних дій учасників бюджетного процесу, способів, порядку, термінів і послідовності їх здійснення [14].

М.В. Скуляк дефініцію «бюджетно-процесуальна норма» пропонує розуміти як встановлені чи санкціоновані державою, а також встановлені місцевим самоврядуванням обов'язкові правила, відповідно до яких регламентується порядок складання та розгляду проектів державного та місцевих бюджетів, їх затвердження та виконання, складання, розгляд і затвердження звітів про виконання цих бюджетів; «бюджетно-процесуальна 
діяльність» як порядок проходження бюджету на підставі бюджетно-процесуальних норм, характерною ознакою якої є те, що вона має циклічний і періодичний характер [15].

Отже, резюмуючи визначення процесуальної норми бюджетного права вищенаведеними вченими, можна сформулювати визначення цієї норми. Під процесуальною нормою бюджетного права (до яких належать також норми, що регламентують порядок виконання бюджетів) слід розуміти загальнообов'язковий, формально-визначений припис, що походить від держави чи муніципальних утворень, охороняється примусовою силою держави, спрямований на забезпечення реалізації матеріальних бюджетно-правових норм за допомогою регулювання процесуальних відносин зі складання, розгляду, затвердження та виконання бюджетів, підготовки, розгляду та затвердження звітів про виконання бюджетів, а також контролю за їх виконанням і внесенням змін в окремі бюджетні показники через закріплення процесуальних дій учасників бюджетного процесу, способів, порядку, строків і послідовності їх здійснення.

Крім того, вбачаємо правильним до складу бюджетно-процесуальних норм, окрім процесуальних норм, пов'язаних із проходженням бюджету (процесуальні норми бюджетного процесу), відносити також процесуальні норми, що регулюють бюджетно-договірні, бюджетно-реєстраційні, бюджетно-контрольні правовідносини та відносини, які виникають із приводу притягнення до бюджетно-правової відповідальності, у разі застосування бюджетно-правових заходів примусу, що не належать до заходів бюджетно-правової відповідальності, та виконання рішень щодо притягнення до бюджетно-правової відповідальності.

Вищезазначена авторська позиція не претендує на першість у науці фінансового права, а слугує черговим етапом розвитку позиції, представленої, зокрема, такими вченими, як А.Г. Пауль, M.I. Сідор, котрі наголошують на процесуальності правил, що встановлюють процедуру застосування заходів примусового характеру за порушення бюджетного законодавства [16].

Висновки. Отже, дослідження сутності інституційних принципів бюджетного права і визначенння напрямів удосконалення бюджетного законодавства з метою забезпечення ефективності в законності бюджетної діяльності, бюджетного процесу і міжбюджетних відносин полягає в тому, що реалізація правових норм (у т.ч. і бюджетнопроцесуальних) складається із засобів і способів правового та неправового характеру, які забезпечують втілення приписів норм права в життя. Характеристика процесу реалізації бюджетнопроцесуальних норм, його механізму зводиться до розгляду особливостей засобів і способів їх реалізації. Не правові засоби і способи реалізації норм традиційно підрозділяються на політичні, економічні та ідеологічні умови, які відіграють важливу роль у процесі реалізації бюджетно-процесуальних приписів, а тому у цьому контексті БКУ потребує внесення змін.

\section{Jimepamypa}

1. Касьяненко Л.М. Процесуальна фінансово-правова теорія: становлення і розвиток : дис. ... докт. юрид. наук : 12.00.07. Ірпінь. 2010. 468 с.

2. Боднарук Ю.В. Податкові провадження в Україні: теоретико-правові засади : дис. ... канд. юрид. наук : 12.00.07. Одеса, 2008. 248 с.

3. Орлюк О.П. Фінансове право. Академічний курс : підручник. Київ : Юрінком Інтер. 2010.808 с.

4. Фінансове право України : навчальний посібник / Л.К. Воронова, М.П. Кучерявенко, Н.Ю. Пришва та ін. Київ : Правова єдність, 2009. 395 с.

5. Пришва Н.Ю. Місце процесуальних норм у регулюванні фінансових правовідносин. Вісник Київського національного університету імені Тараса Шевченка. 2005. № 65-66. C. 10-12.

6. Касьяненко Л.М. Фінансово-правовий процес : монографія. Ірпінь : Національний університет ДПС України. 2010. 505 с.

7. Янкевич С.В. О понятии бюджетного процесса. Общество. Среда. Развитие (Terra Humana). 2011. № 3. C. 94-97.

8. Бюджетний кодекс України : Закон України від 08 липня 2010 р. № 2456-IV, із змінами. URL: zakon2.rada.gov.ua. (дата звернення 14.04.2019).

9. Болтинова О.В. Бюджетный процесс в Российской Федерации: теоретические основы и проблемы развития : дисс. ... докт. юрид. наук : 12.00.14. Москва, 2008. 386 c.

10. Пауль А.Г. Бюджетное право : учебное пособие / под ред. М.В. Карасевой. Москва : Эксмо, 2010. 320 с.

11. Мартыненко В.Е. Правовое регулирование бюджетного процесса в субъекте Российской Федерации: На примере Санкт-Петербурга : автореф. дисс. ... канд. юрид. наук : 12.00.14. Санкт-Петербург, 2006. 19 с.

12. Теленик С.С. Проблеми визначення правовою природи бюджетного процесу. Університетські наукові записки. 2010. № 2 (34). С. 197-200.

13. Теремцова Н.В. Бюджетний процес за законодавством України : дис. ... канд. юрид. наук : 12.0. 07. Одеса, 2009. 224 с.

14. Теремцова Н.В. Бюджетний процес за законодавством України : автореф. дис. ... канд. юрид. наук : 12.00.07 / Київський національний університет імені Тараса Шевченка. Київ, 2010. 16 с.

15. Скуляк М.В. Бюджетний процес на місцевому рівні : дис. ... канд. юрид. наук : 12.00.07 / Класичний приватний університет. Запоріжжя, 2010. 24 с.

16. Сідор М.І. Правовий статус учасників бюджетного процессу : дис. ... канд. юрид. наук : 12.00.07. Одеca, 2011.227 c.

\section{Анотація}

Яворський I. I. Актуальні проблеми визначення процесуальних норм бюджетного права. - Стаття.

У статті розглянуто питання визначення процесуальних норм на сучасному етапі та їх місце в системі бюджетного права. Розкрито та досліджено взаємозв'язок із матеріальними нормами. Досліджено питання сутності й особливостей процесуальних норм бюджетного права та виокремлено сучасні проблемні аспекти 3 визначенням подальших векторів вдосконалення 
вітчизняного законодавства у цій сфері. Проаналізовано специфіку процесуальних норм бюджетного законодавства зарубіжних країн і запропоновано можливі варіанти імплементації зарубіжних норм у вітчиз няну фінансово-правову доктрину. Розглянуто доктринальні підходи щодо розуміння принципів бюджетного права, зміст і значення загально-правових і фінансово-правових принципів, а також ключові категорії бюджетного права - систему бюджетного права, бюджетну діяльність, бюджетні правовідносини. Досліджено сутність інституційних принципів бюджетного права i визначені напрями удосконалення бюджетного законодавства 3 метою забезпечення ефективності в законності бюджетної діяльності, бюджетного процесу і міжбюджетних відносин. Аргументовано позицію про те, що реалізація правових норм (у т.ч. і бюджетно-процесуальних) складається із засобів і способів правового та неправового характеру, які забезпечують втілення приписів норм права в життя. Доведено, що характеристика процесу реалізації бюджетно-процесуальних норм, його механізму зводиться до розгляду особливостей засобів і способів їх реалізації. Не правові засоби і способи реалізації норм традиційно підрозділяються на політичні, економічні та ідеологічні умови, які відіграють важливу роль у процесі реалізації бюджетно-процесуальних приписів. Розкрито, що окремими аспектами виконання бюджетів можна розглядати як процес поступової деталізації прийнятого закону чи іншого акта про бюджет аж до окремих платіжних документів конкретних бюджетоотримувачів (через зведені бюджетні розписи, повідомлення про бюджетні асигнування, кошторису доходів і витрат, ліміти бюджетних зобов'язань).

Ключові слова: бюджет, норма права, процесуальну норма, матеріальна норма, бюджетне законодавство, бюджетна діяльність.

\section{Summary}

Yavorskyy I. I. Actual problems of the definition of procedural norms of budgetary law. - Article.
In the article the questions of determination of judicial norms on the modern stage and their place are considered in the system of budgetary right. Intercommunication is exposed and investigational with material norms. The question of essence and features of judicial norms of budgetary right is investigational and modern problem aspects are distinguished with determination of further vectors of perfection of home legislation in this sphere. The specific of judicial norms of budgetary legislation of foreign countries is analysed and the possible variants of foreign norms are offered in a home financially-legal doctrine. Doctrine approaches are considered in relation to understanding of principles of budgetary right, maintenance and value of juridikal norms and financially-legal principles, and also key categories of budgetary right are the system of budgetary right, budgetary activity, budgetary legal relationships. Essence of institutional principles of budgetary right is investigational and directions of improvement of budgetary legislation are certain with the aim of providing of efficiency in.Position is argued that realization of legal norms (including budgetary-judicial) consists of facilities methods of legal and unlegal character, that provide conversion of binding overs of norms of right in life. It is well-proven that description of process of realization of budgetary-judicial norms, his mechanism is erected, in an eventual account, to consideration of features of facilities and methods of their realization. Unlegal facilities and methods of realization of norms are traditionally subdivided into political, economic and ideological terms that play an important role in the process of realization of budgetary-judicial binding overs. It is exposed, that it is possible to examine the separate aspects of implementation of budgets as a process of the gradual working out in detail passed an act or other act about a budget up to the separate pay documents of concrete budget recipients (through the erected budgetary time-tables, reports about budgetary assignations, estimate of profits and charges, limits of budgetary

Key words: budget, norm right, judicial norm, material norm, budgetary legislation, budgetary activity. 